\title{
Identifying the Qualities of an Ideal Teacher in line with the Opinions of Teacher Candidates *
}

\author{
Hatice Kadioglu Ates ** \\ Sabahattin Zaim University, TURKEY
}

\author{
Serkan Kadioglu $* * *$ \\ Sabahattin Zaim University, TURKEY
}

Received: November 6, 2017 - Revised: December 11, 2017 • Accepted: December 12, 2017

\begin{abstract}
Teaching is a sacred profession performed by self-sacrificing individuals with high responsibilities who are aware of their roles, have undertaken the task of raising future generations, make easier individuals' process of becoming citizen in a way to ensure the peace and welfare of the communities, and allow them to learn knowledge, skills, attitudes and behaviors. By Ataturk's saying, "Teachers are the most devoted and respectable factors of human society all over the world". In hadiths, the sanctity of teaching is expressed as, "Only those two people are admired enviously: The person who uses up and consumes the goods bestowed by Allah on him in the right way, and the person who properly rules over by the wisdom to him by Allah and who also teaches it to others." From early childhood to puberty, the person studying in public institutions establishes a spiritual association with his/her teacher. The psychical aspect of teaching is also quite predominant. The role of teaching is sometimes mixed up with the roles of mother, father, sister and brother. There are many students who keep fresh their relationships with teachers for many years although their education and training activities do not continue. Based on these, the starting point of the study is about which characteristics the teacher must have to become an ideal teacher. This study was carried out to determine the characteristics of an ideal teacher in line with the opinions of the participants of the faculty of education and pedagogical training program in a University in Istanbul. The research was carried out in the screening model. The research data were collected through semi-structured interview technique to find out student opinions in a clearer way. The study group of the research was established in accordance with the voluntary basis from among the students from the psychological counseling and guidance department, Turkish teaching department, gifted children teaching department and English teaching department and the students who are enrolled in the pedagogical training certificate program in a University, in Istanbul, in the 2015-2016 academic year. Face to face interviews were conducted with each participant in the researcher's working office for half an hour on an average. At the beginning of the interview, students were asked about their genders and the graduated university, department and faculty. Within the context of the interview, the question of "what are the characteristics of an ideal teacher for you" was posed to participants. The personal and professional characteristics that an ideal teacher should have were determined according to the opinions of teacher candidates. The discussion section was structured by the research findings in the literature, and the study was finalized with suggestions.
\end{abstract}

Keywords: Ideal teacher, faculty of education students, opinions of prospective teachers, professional characteristics of an ideal teacher, personal characteristics of an ideal teacher.

To cite this article: Kadioglu Ates, H., \& Kadioglu, S. (2018). Identifying the qualities of an ideal teacher in line with the opinions of teacher candidates. European Journal of Educational Research, 7(1), 103-111. doi: 10.12973/eu-jer.7.1.103

\section{Introduction}

Profession is the most important source of personal identity and an area of activity that allows a person to see respect from the environment, establish relationships with others, have a place in the society and feel useful (Kuzgun, 2000). Teaching profession, which is as old as the history of humanity, has assumed varying duties and functions depending on the social structures and cultures in each period. Teachers have indispensable duties and responsibilities in transferring social values and culture to the young generations, achieving a social integration and developing the society (Dogan, 2003). Education is a process that emerges with the inception of man's learning ability and continues for his/her entire life. The fact that man is an educate-able being has brought an important quest and accumulation of knowledge with it (Aydin, 2016). Today that marks a fast-changing world, the objective of education is to bring up individuals that have sufficient competence and qualifications to keep up with the changes of the modern world (Celikten, Sanal and Yeni, 2005). It will be possible to bring up teachers with the desired qualities only when the

\footnotetext{
* This paper was presented orally at the 2nd International Conference on Social Sciences and Education Research (ICSSER) held in Istanbul between November 4 and 6, 2016.

** Corresponding and Main author: Hatice Kadioglu Ates, Department of Primary School Teaching, Faculty of Education, Sabahattin Zaim

University, Istanbul. Email: hatice.kadiogluates@izu.edu.tr

*** Serkan Kadıoğlu, Institute of Social Sciences, Sabahattin Zaim University, Istanbul, Email: serkan1955@hotmail.com
} 
institutions training teachers are accredited for their compliance with the standards regarding the qualities to be given to teachers (Bakioglu, 2014).

Roles imposed on teachers vary based on society, time, circumstances and the principal philosophy of the education program applied. In this global world we live in, the duty of teacher is to protect the identity of the nation and society in which the children and young people live as well as preparing them for such world. To fulfill this burden duly, teachers must first improve themselves. With the awareness that there is no single place (school) and time to gain knowledge, teachers must teach students the learning steps for skills such as living together and put such skills into practice (Saylan, 2014). Teaching is a special area of expertise that requires higher education (Ozdemir and Yalin, 2000). Teaching takes love and heart (Kiziltas, Harmatov and Saricam, 2012). The architect of a nation's future is teachers. It is teachers that bring up politicians, engineers, doctors, lawyers, teachers, military men, police, briefly the man power that serves in every segment of the society, Teachers play very critical roles in the fate of countries. Teachers are the most principal element of the educational system (Celikten, Sanal and Yeni, 2005). Teachers have assumed a heavy responsibility in the performance of an effective educational activity. Among these responsibilities are organizing the educational environment in the classroom, determining the activities, and selecting and using class tools and materials. A teacher that fulfills these functions plays an effective role in the class and has an important impact on both students' learning and personal behaviors during their time at school (Cerit, 2008).

At the center of the education and learning process is students. For them to develop in terms of both knowledge and behavior, teachers must use the school environment that is the formal education institutions effectively. Since students spend the important parts of their lives at school, there are important responsibilities teachers assume during this process (Gunduz, 2014).

Classrooms are structured environments where teachers and students share their knowledge and experiences to achieve the educational goals, Behaviors exhibited by teachers in classroom have a major impact on the level of achievement of these educational goals (Kilic, Kaya, Yildirim and Genc, 2004). The prerequisite for a quality education is a qualified teacher (Adiguzel, 2005). It is inevitable to apply due diligence in selecting candidates for a sensitive profession such as teaching and hiring the most suitable candidates (Yilman, 2006).

Personality of a teacher affects his/her efficiency as well as the students and their learning (Tezcan, 1997). Selecting candidates who love and prefer the teaching profession may be suggested as the first step of bringing up qualified teachers. However, as in other professions, individuals do not choose their professions only based on their desire and abilities, which will naturally affect the attitude toward teaching in different ways (Ekinci, 2017). Teaching is an extremely important profession in terms of human sensitivities. Those who chose this profession are expected to be sensitive enough toward people whom they will serve. This sensitivity is associated with the personal qualities. Level of sensitivity of people who choose teaching profession affects their mental health as well. For, the profession is performed not only to meet the economic requirements but also to achieve psycho-social development and satisfaction (Yazici, 2009).

Due to the role teachers play in founding the society's future and shaping the future generations, the teaching profession is always vulnerable to political and social interest and pressure. That is maybe why competencies and qualities required from teachers are always under discussion and the programs of institutions training teachers are changed due to such discussion (Sahin, 2014). In recent years, a teacher model has been defined by reformists and the media increasingly as a professional that is intelligent, has received a liberal education and values social life. This teacher model strictly adheres to one or more fields of science and works smartly to make knowledge accessible and useful for students. Whatever the image created by this type of teacher, and his/her needs, talents or circumstances may be, he/she fits the portrait of a person that helps students become successful. It is obvious that what people seek in teachers is more than the talents of transferring the content and giving skills to students. Teachers demonstrate what it means to be an enlightened, hard-working, virtuous and educated person by means of their words and acts. Teachers shape both students and themselves in line with such impression of the society (Celikten, Sanal and Yeni, 2005).

Selecting teacher candidates are as important as the teacher teaching programs. Knowing the views of candidates selected for the teaching profession on the profession itself is regarded to be one of the important criteria in organizing learning activities. Education-learning activities have a number of important dimensions from the quality of the programs to their application, from time to teaching technologies used, from management and inspection to education employees. Teaching requires professionalism. However, apart from this, teaching profession is also closely related with the individual views and behaviors of the people who will perform this profession (Ozbek, Kahyaoglu and Ozgen, 2007).

The principal duty expected from schools is to bring up students according to the conditions of the time and the needs of the society. The reason of existence for schools is students, and that's why, a transformation in an education system must aim to help students learn better. In a knowledge-based society, students are expected to graduate from school having learned how to produce thoughts, and use casual thinking and their minds (Avci and Durmuscelebi, 2014). 
The objective of the education system today must be to bring up entrepreneurs who can keep up with the change of the time, is creative, undertaker and in a sense, can think globally and act locally (Ozden, 2005). A teacher is the person that constantly interacts with students, implements the education program, manages the learning and evaluates both the students and teacher. Therefore, qualities of a teacher greatly affect the quality of these processes as well (Bircan, 2003).

While education programs, methods and techniques and tools and materials are important factors to develop the education, they won't be as effectual as desired unless they are put into practice by the very person of the teacher. In this respect, it is very important that teachers undergo a quality pre-service training. As in all professions, the teaching profession also requires that the basic qualities of the person who can successfully perform this profession be known. These qualities could be determined by profession-related institutions, persons and groups (Ozabaci and Acat, 2005).

Seferoglu (2004) suggested that an effective education was only possible with qualified teachers. Bringing up qualified teachers is the most important component of the education system in all societies. Training teachers for various levels and areas in the education system is an extremely important and determinative matter. In training qualified teachers, the effect of the participation of candidates that consciously select the teaching profession on the increased quality of the profession can be predicted. Therefore, research that identifies the factors of why teachers and teacher candidates prefer the teaching profession appears to be important.

The fast-changing conditions of the world bring a new dimension to the changing human relationships and communication. Class environments are also affected by this change. Students want to feel more as an individual while learning and demand a more sensitive communication (Ozabaci and Acat, 2005).

While determining the education programs, the requirements of the society, changing conditions and the developments in the teaching profession must be taken into consideration in light of the country's rich experience in teacher training and thereby teacher education programs must be brought to such level as to meet the social and professional requirements. And for these programs to achieve their goals, teachers teaching teachers must be equipped with knowledge, skills and scientific approach that will be best to train teacher candidates professionally. With the changing conditions and requirements of today, the conventional teacher model based on transferring knowledge is replaced by a teacher model that teaches how to reach information sources. Teacher candidates must be brought up with such an approach as to produce and provide knowledge, facilitate learning by using teaching methods and strategies suitable for the student level, create a democratic and organized environment in the classroom, develop effective communication skills, understand the functions of the school and the responsibilities of the profession and be a role model (Sahin, 2014).

Primary education is an educational level that has an important contribution to the education of the individuals and the shaping of their future lives, and because of being the first step of the education process, forms the foundation of the entire education life. Teachers that are responsible for organizing the education environment that the students encounter and are regarded by the students as a role model are an important element of the teaching process (Cerit, 2008).

A teacher's success is in parallel with his/her success in the learning-teaching process. Therefore, a teacher's effective and proper use of the teaching skills ensures a skillful management of the learning as desired. Effective teachers are those who are equipped with professional knowledge and skills. Particularly, teachers are expected to be acquainted with the goals required from them in terms of their teaching skills and acquire effective practical skills accordingly before entering service (Bayindir, Cavdar and Gokce, 2016).

Competence is the state of having the required professional knowledge, skills and attitudes to perform duties specific to an area of profession. The concept of teacher competencies, on the other hand, is the knowledge, skills and attitudes required to perform the teaching profession effectively and efficiently. The overall competencies for the teaching profession are defined as personal and professional values, professional development, knowing the students, teaching and learning process, monitoring and assessing learning and development, school, family and community relations, and program and content knowledge. Key competencies are divided into sub competencies. Behaviors that can be observed and measured with performance indicators and may serve as the evidence of whether or not competencies are achieved have been defined (Tanriogen and Sarpkaya, 2014).

Overall competencies that began to be defined in Turkey in 2004 were put into effect with the ministry's approval in 2006. Overall competencies were defined in line with the European Teacher and Educator Overall Competencies, European Framework for Competencies, Basic Education Support Program and articles 43 and 45 of the Basic Law of National Education 1739. Teacher competencies are considered to be used in defining the teacher training policies, preservice teacher training programs of the higher education institutions training teachers, in-service trainings for teachers, selection of teachers, assessment of work success and performance of teachers and teachers' achievement of self-awareness and career development (MEB, 2012). Areas of competency and sub competencies are as follows: 
1. Personal and Professional Values - Professional Development; valuing, understanding and respecting students, believing that students can learn and succeed, valuing national and universal values, doing self-evaluation, achieving personal development, monitoring and contributing to professional developments, adhering to professional codes and fulfilling the duties and responsibilities.

2. Knowing the Student: Paying attention to their developmental characteristics, their interests and needs, valuing students, and guiding students.

3. Learning and Teaching Process: Course planning, material preparation, organizing learning environments, diversifying the extracurricular activities, paying attention to individual differences and diversifying the teaching, time management, and behavior management.

4. Monitoring and Evaluating Learning and Development: Defining assessment and evaluation methods and techniques, assessing student learning using different assessment techniques, analyzing and interpreting data - providing feedback, teaching based on results - reviewing the learning process.

5. School-Family and Community Relations: Knowing the environment, using the environmental opportunities, making the school a cultural center, knowing the family and being impartial in relationships with families, ensuring family participation and cooperation.

6. Program and Content Knowledge: Objectives and principles of the Turkish national education, knowledge of and implementation skills for special field teaching program, monitoring-evaluating and improving special field teaching program.

Professional skills required from effective teachers may be listed as attracting students' attention, diversifying the activities, using teaching time effectively, asking students questions that induce thinking, conducting clear/intelligible teaching, monitoring student development, providing feedback and providing reinforcers. Teacher's personal qualities can be listed mainly as warmth, sense of humor, reliability, high success expectation, motivation, systemness, adaptation/flexibility, and knowledgeableness. An understanding of education moving from the conventional to the contemporary can lead to significant changes also in teacher roles in parallel to the social developments. Today, the understanding of teacher that knows everything has been replaced by one that guides learning. Teacher's role has been defined as guiding the learning and teaching process, organizing the learning environment and planning the evaluation activities (Tanriogen and Sarpkaya, 2014).

The education literature is rich in studies on teaching as a profession and teachers. In the literature, "good teacher" is a prototype concept that refers to a generally recognized ideal. However, in reality, this concept contains a wide range of qualities and characteristics. The ideal teacher image has become a topic directly and indirectly discussed by the educational philosophy in various theories for ages. From the beginning of the western civilization until today, philosophers and thinkers have presented a prototype of ideal teacher with values and principles generally reflecting the educational perception and argument of the thinker or the philosophy (Reichel and Arnon, 2009 as cited by Sahin, 2014). The purpose of this study is to identify the qualities of an ideal teacher with the views of the teacher candidates, in Istanbul. For this purpose, answers to the following sub questions were sought:

1. What are the qualities of an ideal teachers according to the views of teacher candidates participating in the research?

\section{Method}

This research that aims to identify the views of teacher candidates on the qualities of an ideal teacher, used phenomenological design, which is one of the qualitative research methods. Phenomenological design focuses on a phenomenon of which we are aware but do not have a deep and detailed understanding. Phenomenology constitutes an appropriate research basis for studies that investigate a phenomenon that are not fully strange to us but of which we cannot fully comprehend the full meaning (Yildirim and Simsek, 2008).

The study group in this research is comprised of volunteer students who study Pre-School Teaching, English Teaching, Guidance and Psychological Counseling, Gifted Students Teaching, Turkish Teaching and Pedagogics Formation Certificate Program of a university, in Istanbul. There are 380 teacher candidates studying at all of departments. Each participant was interviewed in person at the researcher's office for about half an hour. Before the face-to-face interviews, teacher candidates were reached to determine a day and time they were available. Face-to-face interviews were conducted at the researcher's office at the school where teacher candidates study. Teacher candidates' views were collected at their school, in their own natural environment through observations. Face-to-face interviews took half an hour (20-40 minutes) on average. Before the interviews, the participants were asked for permission for audio recording. Afterwards, interviews were converted to written form with the participation of the researcher and the experts. During the interview, the participants were asked the question of "What are the qualities of an ideal teacher?" Personal and professional qualities an ideal teacher must have were defined according to the views of teacher candidates. The research was conducted with candidates that participated voluntarily between September and March during the 2015-2016 academic year. Semi-structured interview technique exhibits a technical look that is more 
appropriate in educational science research due to its certain standard level as well as its flexibility (Ekiz, 2003). In the research, data was analyzed using a qualitative data analysis technique, namely content analysis. The basic purpose of the content analysis is to derive concepts and relationships that can explain the data collected. The procedure in the content analysis is to group similar data together within the framework of specific concepts and themes and organize and interpret them in such way as enables the reader to understand the data (Yildirim and Simsek, 2008).

Analysis process was performed separately and independently by both researchers. Later, the data was compared to check the internal consistency. Also, analyzed data was written down and sent to the members of the study group by electronic mail for checking. Thus, the participants' confirmation was obtained and both interview and written forms of the data were created. This way, it was attempted to overcome the limitations of a data collection method. Yildirim (2010) and Yildirim and Simsek (2008) state that data diversification may contribute significantly to the increased validity and reliability of the findings derived from a research. In qualitative research, another way used to ensure validity and reliability is to obtain participant confirmation (Johnson, 1997; Merriam, 1995; Yildirim, 2010). Research findings were presented to the participants and made in final form upon the approval received from them. During this process, all of the participants were reached to obtain their feedback on the findings.

In order to ensure the reliability of the research, four experts were consulted for their opinion. One of the experts is a professor working as a dean of the faculty of education at a public university. Two of the experts work as an assistant professor in the faculty of education at a foundation university in Turkey. One expert is an associate professor at a public university in Istanbul. While three of the experts have a doctoral degree in educational sciences, one expert has a doctoral degree in teacher training program. In comparisons, agreements and disagreements were identified and the research reliability was calculated using Miles \& Huberman's (1994) formula (Reliability=agreement/(agreement+disagreement)). In qualitative studies, the concordance between the expert and researcher evaluations that is $90 \%$ or above suggests a desired level of reliability. In the reliability study conducted specifically for this research, a 92\% consensus (reliability) was achieved. In respect of validity, on the other hand, describing the collected data in detail and the researcher's explanation of how she/he reached the results are among the important criteria of validity (Yildirim and Simsek, 2008).

\section{Findings}

Responses of the teacher candidates regarding the qualities of an ideal teacher were observed to group under two different headings (personal qualities, professional competencies related to teaching and area of expertise).

\section{(1) Personal Qualities}

Reliable, understanding, tolerant, fair, objective, impartial, patient, helpful, not castigating, attentive, social, affectionate, positive, humble, witty, dynamic, planned, systematic, well-equipped, well-groomed, kind, clean, rigorous, virtuous, well-behaved, conscientious, innovative, knowledgeable, modern, authoritarian, sympathetic, honest, civilized, calm, democratic, resolved, tenacious, intelligent, controlled, supportive, motivating, holistic, punctual, polite, fun, friendly, constructive, undertaker, productive, considerate, educator, qualified, agreeable, mild, unselfish, idealist, selfsacrificing, energetic, having no complexes, philanthropic, art lover, candid, flexible, stable, righteous, chic, creative, experienced, original, transparent, emotional, consistent, qualified, modern, organized, strong, happy, intellectual, contended, participator, brave-courageous, sharing, perfectionist, using effort to do his/her best, not dismissing someone who comes to the teachers' room or his/her office, not reflecting his/her boredom/frustration/private life on students, not having a fixed mindset, not being prejudiced toward students, not reflecting his/her problems on the class, full of love, loving children-people, not being self-centered, nice-looking, being principled, having a high selfconfidence, not imposing his/her political views, not being prejudiced, not discriminating, well-intentioned, mildmannered, having a good character, good-natured, having responsibility goals, knowing what he/she wants, making and applying decisions quickly, being successful in crisis management, not being hurtful, not looking down on students, having no psychological problems, having no financial concerns, not valuing material things, not pouting, not having taboos, not making comparisons, not being reactive, not disclosing his/her private life, not being egoist, not being oldfashioned, not satisfying his/her ego on students, not praising herself/himself constantly, not putting pressure on students, not doing any derogatory behaviors or using derogatory words, having a good diction, speaking Turkish well, being able to express herself/himself well, keeping his/her promises, having a high general culture, highly communicative, preparing students for life, open to innovation, having a good command of the language, having an impressive tone of voice, showing empathy, creating science, being current, being a human first, speaking fluently, not telling about his/her memories during the entire class, not having a typical civil servant mindset, not being a stranger to the society's cultural structure, not having problems expressing himself/herself, humanist

\section{(2) Professional Competencies Related to Teaching and Area of Expertise:}

Being a teaching leader, having leadership qualities, having a reading culture, using effort to add value to his/her institution, protecting the interests of his/her institution, paying regard to his/her institution's values, acting like a mirror to reflect truth, shedding light for students, committed to his/her profession, having a high comprehension skill, 
having had psychology education, expressing his/her expectations to students clearly and openly, not intimidating with grades, making himself/herself listened to, being able to guide, not running around in circles, teaching how to learn, improving himself/herself while teaching, not having a diminished teaching enthusiasm, having influence, being able to teach how knowledge can be used for the benefit of humanity, inducing enthusiasm for science, advocating modern understanding of education and not teaching traditionally, not circumventing questions asked, not reciting slides, remembering that he/she was once a student, learning by doing and living, not giving hard and too many assignments above the development level, not discriminating between good and bad student, not being frugal about grades, not deviating from the topic/subject.

\section{Conclusion, Discussion and Recommendations}

The followings are the studies that are in parallel with the research results:

Generally, competencies required from teacher are divided into two groups including personal competencies and competencies related to subject area and education. Personal competency can be defined as high personal responsibility, creativity, ability to solve problems, critical thinking, teamwork, ability to initiate change, understanding, compassion and tolerance, high social relationships and moral values. Subject area competencies refer to the requirement of the quality and quantity of professional knowledge related to the subject matter in a specific area. Educational competency is related to educational work of a teacher, particularly learning (Sunbul, 2006).

The results of an applied study conducted by Celikten and Can (2003) on ideal teacher are also in parallel with the qualities listed and described above. According to the said researchers, an "Ideal Teacher" must be good-humored, tolerant, affectionate, reliable, honest, impartial, confidant and friend toward students and be a role model for students with his/her thoughts and behaviors. Teacher's focus on success and high expectations from students are among the teacher qualities deemed by teachers to be very important.

All stakeholders agree that a good teacher must have both educational competency and subject matter competency. In addition, it is also emphasized that a teacher must be tolerant, affectionate, understanding, witty, open-minded, encouraging, supportive etc. (Sarpkaya, 2005).

As a result of the study conducted by Cetin (2001), the qualities of an ideal teacher are listed as working with students in a friendly manner and in cooperation, understanding student's character and needs, being respectful toward students and loving them.

The teacher candidates describe ideal teacher as the one that provides multiple examples while teaching a class, does not bore students, loves, respects and values students, is knowledgeable in the subject matter, has a good command of his subject, researches, improves himself/herself, is good-humored, candid and sincere, manages the class well, is disciplined, motivating and supportive, is kind but firm, treats friendly, treats everyone equally, prepares students for life, is as compassionate as a mother, approaches fatherly, makes students love the class, and understands and listens to his/her students (Caliskan, Isik and Saygin, 2013).

Ideal teachers and faculty members are those that establish a healthy pedagogical relationship with students. A relationship achieved this way is both the product and foundation of a teacher's professional success (Bilen, 1995).

A teacher must pay attention to all students in the class, ensure their participation in the class and organize his/her verbal and non-verbal behaviors in such way as to improve student success (Ergun, Duman, Kincal and Aribas, 1999).

Ozabaci and Acat (2005) list the 10 qualities the students of the faculty of education consider that the ideal teacher must have as follows: Loving his/her profession, having a good command of language, being able to communicate, loving his/her job, being informative, honest, reliable, democratic, knowledgeable and well-read.

A teacher personality that facilitates others' development must be one of the principal focuses of education (Kilicci, 1992).

Ozdemir and Yalin (2000) summarized the personal qualities of an effective teacher in three groups including motivating personality, commitment to success and professional behavior.

Academic success is not sufficient alone in upbringing qualified teachers. Personal qualities required for teaching profession are not sought in teacher candidates appointed via the centralized examination system. These examinations only measure the academic success of the candidates. Teacher candidates who have some negative personal qualities will inevitably experience some problems in their professional lives (Ari, 2015).

Crowded classrooms, the abstract nature of the subjects, and insufficient physical environment come up as factors that prevent students from constantly focusing on the classes. Knowledge included in the theoretical knowledge base of the teachers such as knowledge on students' development characteristics, appropriate class management and strategies, effective teaching methods, and supporting teaching technologies etc. is used by teachers in an effort to maintain the group performance at the highest level (Sonmez, 2013). 
A university student expects to be shown respect. He/she prefers a professor that values, listens to and is kind and sincere to him/her, is not arrogant and is reliable, rather than underestimating, castigating, insulting, humiliating, and despising him/her. He/she looks for a professor that is approachable, can be asked questions, is pessimist, and is kind but firm. In the meantime, in case students cannot solve their problems alone, they also appear to prefer professors that pay attention to their problems, develop solutions and help them sincerely. As for qualities related to learningteaching, they appear to prefer professors that come together with different groups, are good at teaching the class, make the students feel relaxed with humor, make the class attractive, provide examples, are suitable for students' psychology and level, teach the class by using Turkish well. Following the above, there appears to be significant frequency connected with their preference of professors that have high scientific competency, have a good command of the course subject and are good scientists. Also, they want professors to be impartial in their evaluations and not to use grades as a threat (Ergun et al, 1999).

Cetin (2001) identified that students described an ideal teacher as one that had the habit of working with students in a friendly manner and in cooperation, had full knowledge of the subject matter, understood student's character and needs, did not have any general education and scientific behavior incompetence, and was respectful, full of love, and able to analyze the individual differences among the students and use various methods and techniques during the class.

In another study conducted by Arnon and Reichel (2007) to identify the qualities required from an ideal teacher, students referred to the personal qualities as the first quality an ideal teacher must have (showing empathy, being a leader, having broad general cultural knowledge) (as cited by Caliskan et al, 2013).

It is quite meaningful that having a philosophy of the world he/she lives in and education are described as one of the most important criteria for a teacher to be considered successful. While what is ultimately required from a teacher is to educate people, what is required for this is that he/she must consider human/humanity as a value and create a value for both the individual being educated, himself/herself and the humanity (Hesapcioglu, 2008; as cited by Bakioglu, 2014).

Teaching is a sacred profession that assumes the role of educating future generations, enabling citizenization of individuals in such manner as ensures peace and prosperity of societies and teaches them knowledge, skills and behaviors, and is performed by devoted individuals who are aware of their roles and have a high sense of responsibility. People who receive education from early childhood to adolescence in educational institutions establish a spiritual relationship with their teachers. Teaching profession's spiritual aspect is also very dominant. In the present study, personal and professional qualities an ideal teacher must have were defined according to the views of teacher candidates, in Istanbul. Future studies may restructure the qualities of an ideal teacher by asking the parents, school administrators, educational inspectors, primary, middle and high school students and teachers. Also, a form may be prepared with respect to the qualities of an ideal teacher and a new research may be conducted by asking teachers as to how well they achieve these qualities. A literature research may be conducted about the qualities of an ideal teacher based on the research findings. A new study may be conducted on the perception of ideal teacher in different countries.

\section{References}

Adiguzel, A. (2005). Avrupa Birligine Uyum Surecinde Ogretmen Niteliklerinde Yeni Bir Boyut: Bilgi Okuryazarligi (,A New Dimension in Teacher Qualifications in European Union Alignment: Information Literacy). Milli Egitim, 167, 355-364.

Ari, A. (2015). Ogretmeni Secmede Ogretmen Adaylarinin Kisilik Ozelliklerinin Belirlenmesinin Onemi (The Importance of Determining Personality Traits of Teacher Candidates in Choosing Teachers). Elementary Education Online, 14(3), 862-873, DOI: 10.17051/io.2015.34960

Avci, O, Durmuscelebi, M. (2014). Ogretmen Goruslerine Gore Ideal Ogrenci Tipi (Ideal Student Type According to Teacher's Opinions). OPUS Uluslararasi Toplum Arastirmalari Dergisi, 4 (6), 22-44. Retrieved from http://www.edergi-marmara.dergipark.gov.tr/opus/issue/22695/242286

Aydin, I. (2016). Yonetsel Mesleki ve Orgutsel Etik (Managerial Professional and Organizational Ethics). Ankara: PegemA Yayincilik.

Bakioglu, A. (2014). Egitim Bilimine Giris (Introduction to Educational Science). (Ed.). Ankara: Nobel.

Bayindir,N., Cavdar, H. ve Gokce, M. (2016). Ogretmen Adaylarinin Ideal Ogretimsel Becerilere Iliskin Beklentileri (Teacher Candidates' Expectations for Ideal Instructional Abilities). Usak Universitesi Sosyal Bilimler Dergisi, 9(1), 79-88.

Bilen, M. (1995). Plândan Uygulamaya Ogretim (Teaching Practice from Plans). Ankara: Ankara Basim.

Bircan, I., (2003). Egitimde Yeni Yonelimler (New Directions in Education). Cagdas Egitim Sistemlerinde Ogretmen Yetistirme Ulusal Sempozyumu. Ankara, Bildiriler Kitabi, 44-47. 
Cerit, Y. (2008). Ogretmen Kavrami Ile Ilgili Metaforlara Iliskin Ogrenci, Ogretmen ve Yon eticilerin Gorusleri (Opinions of Students, Teachers and Administrators on the Metaphor of Teacher Concept). Turk Egitim Bilimleri Dergisi, 6 (4): 693-712.

Caliskan, M., Isik, A. N., \& Saygin, Y. (2013). Ogretmen adaylarinin ideal ogretmen algilari (Ideal teacher perceptions of teacher candidates). Ilkogretim Online, 12(2), 575-584.

Celikten, M. ve Can, N. (2003). Yonetici, Ogretmen ve Veli Gozuyle Ideal Ogretmen (Ideal Teacher with Manager, Teacher and Parent). Selcuk Universitesi Egitim Fakultesi Dergisi, 15(2), 253-267.

Celikten, M., Sanal, M., \& Yeni, Y. (2005). Ogretmenlik Meslegi ve Ozellikleri (Teaching Profession and Characteristics). Erciyes Universitesi Sosyal Bilimler Enstitusu Dergisi, 19(2), 207-237.

Cetin. S. (2001). Ideal Ogretmen Uzerine Bir Arastirma (A Research on the Ideal Teacher). Milli Egitim, 149.

Dogan, M. C. (2003). Turkiye'de Ogretmenlik Mesleginin Sorunlari ve Ogretmen Adaylarinin Meslege Iliskin Goruleri (Relating to the Profession of Teaching Profession eyesight problems and Teachers in Turkey). Istanbul: Burak yayinlari.

Ekinci, N. (2017). Ogretmen Adaylarinin Ogretmenlik Meslegi ve Alan Seciminde Etkili Olan Motivasyonel Etkenler (Motivational Factors Affecting Teaching Profession and Teacher Candidate Selection). Ilkogretim Online, 16(2), 394-405, 2017. [Online]:http://ilkogretim-online.org.tr doi: 10.17051/ilkonline.2017.304706.

Ekiz, D.(2003). Egitimde Arastirma Yontem ve Metotlarina Giris (Introduction to Research Methods and Methods in Education). Ankara.

Ergun, M., Duman, T., Kincal, R. K. ve Aribas, S. (1999). Ideal Bir Ogretim Elemaninin Ozellikleri (Characteristics of an Ideal Instructor). Afyon Kocatepe Universitesi Sosyal Bilimler Dergisi, 3, 1-11.

Gunduz, M. (2014). Ilkokul Ogrencilerinin Etkili Ogretmen Hakkindaki Dusunceleri (Thoughts of Primary School Students about Effective Teachers). YYU Egitim Fakultesi Dergisi, 11(1), 114-128.

Jhonson, R. B. (1997). Examining the validity structure of qualitative research. Education, Winter, 118(2), 282-292.

Kilic, M., Kaya, A., Yildirim, N., Genc, G. (2004). Egitimci gozuyle ogretmen ve ogrenci (Educator is eye-catching teacher and student). XIII. Ulusal Egitim Bilimleri Kurultayi, 6-9 Temmuz 2004, Inonu Universitesi Egitim Fakultesi, Malatya.

Kilicci, Y. (1992). Okulda Ruh Sagligi (Mental Health at School). Ankara: Safak Matbaacilik.

Kiziltas, E., Halmatov, M. ve Saricam, H. (2012). Okul oncesi ogretmenligi ogrencilerinin ogretmenlik meslegine yonelik tutumlari (Attitudes of pre-school teachers towards their teaching profession). Mehmet Akif Ersoy Universitesi Egitim Fakultesi Dergisi, 23, 173-189.

Kuzgun, Y. (2000). Meslek danismanligi (Occupational counseling ). (2nd Edition) Ankara: Dogus Matbaacilik.

MEB (2012). Ogretmenlik meslegi genel yeterlikleri (Teaching profession general competencies). www.otmg.meb.gov.tr/YetGenel.html

Merriam, S.B. (1995). What can you tell from an $\mathrm{N}$ of 1?: Issues of validity and reliability in qualitative research. PAACE Journal of Lifelong Learning, 4, 51- 60.

Metin, M. ve Aytac, T. (2015). Egitim Bilimine Giris (Introduction to Educational Science). (Ed.). Ankara: Pegem Akademi.

Miles, M. B. \& Huberman, A.M. (1994). Qualitative data analysis: An expanded sourcebook. (2nd Edition). Calif.: SAGE Publications.

Ozabaci, N \& Acat, M.B. (2005). Ogretmen Adaylarinin Kendi Ozellikleriyle Ideal Ogretmen Ozelliklerine Donuk Algilarinin Karsilastirilmasi (Comparison of Teacher Candidates' Perceptions towards their Ideal Teacher Characteristics). Kuramdan Uygulamaya Egitim Yonetimi, 11(42) 195-209.

Ozbek, R., Kahyaoglu M. ve Ozgen, N. (2007). Ogretmen adaylarinin ogretmenlik meslegine yonelik goruslerinin degerlendirilmesi (Evaluation of teacher candidates' views towards teaching profession). Afyon Kocatepe Universitesi Sosyal Bilimler Dergisi, Cilt: IX, Sayi: 2, Aralik 2007.

Ozdemir, I. ve Yalin, H. (2004). Ogretmenlik Meslegine Giris (Introduction to Teaching Profession). Ankara: Nobel Yayin

Ozden, Y. (2005). Egitimde Yeni Degerler (New Values in Education). Ankara: PegemA Yayincilik.

Sarpkaya, R. (2005). Bir Meslek Olarak Ogretmenlik. Ogretmenlik Meslegine Giris (Teaching as a Profession. Introduction to Teaching Profession). (2nd Edition) (Ed. Musa Gursel, Muhsin Hesapcioglu). Konya: Egitim Kitabevi. 
Saylan, N. (2014). Egitim Bilimine Giris (Introduction to Educational Science). (Ed.) (8th Edition). Ankara: Pegem Akademi.

Seferoglu, S.S. (2004). Ogretmen Yeterlikleri ve Mesleki Gelisim (Teacher Competencies and Professional Development).

Bilim ve Aklin Aydinliginda Egitim Dergisi, Yil 5, Sayi 58.

Sonmez, V. (2013). Egitim Bilimine Giris (Introduction to Educational Science). (Ed.) (10th Edition). Ankara: Ani.

Sunbul, A. M. (2006). Bir Meslek Olarak Ogretmenlik. Egitim Bilimine Giris (Teaching as a Profession. Introduction to Educational Science). (Ed. Ozcan Demirel, Zeki Kaya). Ankara : Pegem A Yayincilik.

Sahin, I. (2014). Ogretmen Adaylarinin Nasil Yetistirildiklerine Iliskin Gorusleri (Opinions of How Teacher Candidates Are Raised). Kastamonu Egitim Dergisi, 22(1), 241-258.

Tanriogen, A. ve Sarpkaya, R. (2014). Egitim Bilimine Giris (Introduction to Educational Science). (Eds.) (5th Edition). Ankara: Ani.

Tezcan, M. (1997). Turk Kisiligi ve Kultur-Kisiligi Iliskileri (Turkish Personality and Culture-Personality Relations). Ankara: Kultur Bakanligi Yayini.

Yazici, H. (2009). Ogretmenlik Meslegi, Motivasyon Kaynaklari ve Temel Tutumlar: Kuramsal Bir Bakis (Teaching Profession, Motivation Sources and Basic Attitudes: A Theoretical Perspective). Kastamonu Egitim Dergisi, 17 (1), 33-46.

Yildirim, A., \& Simsek, H. (2008). Sosyal bilimlerde nitel arastirma yontemleri (Qualitative research methods in the social sciences). Ankara: Seckin Yayinevi.

Yildirim, K. (2010). Nitel Arastirmalarda Niteligi Artirma (Increasing Qualification in Qualitative Research). Ilkogretim Online, 9(1), 79- 92.

Yilman, M. (2006). Turkiye'de Ogretmen Egitiminin Temelleri (Fundamentals of Teacher Education in Turkey). Ankara: Nobel Yayin Dagitim.

Yurdagul, H., Erdem, M. ve Seferoglu, S. S. (2010). Ogretmenlik Meslegi Genel Yeterliklerine Iliskin Ogretmen Yetistiren Kurumlardaki Ogretim Elemanlarinin Gorusleri (Opinions of the Instructors in Institutions Training Teachers Adapted to General Competencies of Teacher Profession). Uluslar arasi Ogretmen Yetistirme Politikalari ve Sorunlari Sempozyumu II, 16-18 Mayis 2010 - Hacettepe Universitesi, Beytepe-Ankara. 